\title{
PENGEMBANGAN SISTEM ELEKTROPLATING BERBASIS IMAGE PROCESSING
}

\author{
Luki Utomo \\ Jurusan Teknik Elektro FT UNPAM \\ JIn. Puspiptek Raya No 11 Buaran, Tangerang Selatan 15310 INDONESIA \\ dosen00904@unpam.ac.id
}

\begin{abstract}
ABSTRAK
Penelitian tentang pengembangan sistem elektroplating menggunakan image processing yang telah dilakukan pada dasarnya merupakan pengolahan citra digital yang dikolaborasikan dengan sistem elektroplating. Hal ini dilakukan karena pada sistem yang lama proses penentuan luasan objek masih sulit dilakukan secara langsung. Oleh karena itu tujuan penelitian ini adalah mengembangkan metode image processing untuk menentukan luasan objek yang akan dilapisi. Terdapat beberapa metode yang digunakan yaitu pertama metode HSV (Hue Saturation Value), yang kedua metode flood fill, yang ketiga metode get pixel, dengan menggunakan metode ini dapat menghitung jumlah piksel yang telah dilakukan proses flood filling, dari jumlah piksel yang terdefinisi, dilakukan proses kalibrasi untuk menentukan luasan per piksel, yang nantinya luas diperoleh dari nilai piksel yang terkalibrasi dikalikan dengan banyaknya piksel yang terhitung. Terdapat beberapa parameter yang memiliki nilai konstan seperti waktu pelapisan selama 39 detik pada bahan nickel \& 360 detik untuk tembaga, sedangkan untuk parameter tegangan bernilai 7,5 volt untuk nickel \& 4,36 volt untuk tembaga. Hasil dari penelitian yang dilakukan berupa data parameter yang nantinya akan disimulasikan pada program simulasi yang dibuat dengan menggunakan Borland Delphi. Dapat disimpulkan bahwa luasan yang diukur dengan metode image processing akan menghasilkan parameter yang tepat untuk proses elektroplating.
\end{abstract}

Kata kunci: Image Processing, Luas Objek, Hue Saturation Value (HSV), Flood Fill, Get Pixel, Borland Delphi

\begin{abstract}
Research about the development of electroplating system using image processing that has been done basically a digital image processing system collaborated with electroplating. This is done because in the old system the process of determining the extent of the object is still difficult to do directly. Therefore, the purpose of this research is to develop the image processing method to determine the extent of the object to be coated. There are several methods used is the first method of HSV (Hue Saturation Value), the second method of flood fill, the three methods get pixel, using this method can calculate the number of pixels that have made the process of flood filling, from the number of pixels is defined, a process calibration to determine the extents per pixel, which will be widely obtained from a calibrated pixel value multiplied by the number of pixels is counted. Parameters in the electroplating process that is associated with the results of image processing that is current, current density, thickness and plating time. There are some parameters that have a constant value like a coating time for 39 seconds on the material of nickel and 360 seconds for copper, while the voltage parametervalue of 7.5 volts to 4.36 volts for nickel and copper. The results of the research conducted in the form of data parameters that will be simulated in the simulation program created by using Borland Delphi. It can be concluded that the area measured by the image processing method will produce the appropriate parameters for the electroplating process.
\end{abstract}

Keywords: Image Processing, Extent of the Object, Hue Saturation Value (HSV), Flood Fill, Get Pixel, Borland Delphi 


\section{PENDAHULUAN}

Proses elektroplating yang berkembang sekarang ini mayoritas terbatas pada ukuran, jenis benda, luas permukaan dan komponen penting lainnya yang masih bersifat manual karena untuk melakukan proses tersebut parameter proses harus dikalibrasi secara manual terlebih dahulu. Dari beberapa parameter penting yang ada pada proses elektroplating, parameter luas permukaan benda merupakan salah satu komponen yang akan diteliti sebagai acuan penentuan parameter lainnya dalam proses elektroplating. Penelitian sebelumnya hanya membahas mengenai optimasi waktu dan jarak elektroda terhadap ketebalan dan kekerasan lapisan krom pada stoneware dan earthenware.[8]

Tujuan penelitian ini yaitu untuk memudahkan dalam melakukan pengaturan nilai parameter luas permukaan benda yang akan dilapisi. Fleksibilitas pada proses penentuan nilai parameter pada sistem elektroplating diharapkan dapat membuat industri elektroplating tidak monoton dalam melakukan prosesnya, dalam arti sempit tidak hanya produk dari internal pabrik saja tetapi setiap benda dari eksternal pabrik yang nantinya akan diproses tidak mempunyai kesulitan dalam menentukan nilai luasan secara real time sehingga dapat meningkatkan nilai produktifitasnya. Beberapa metode dalam image processing digunakan untuk menghitung luas area yang dicapture dengan sebuah webcam. Beberapa metode diantaranya HSV, flood fill dan get pixel, dimana penentuan nilai luasan suatu benda atau objek yang akan dilapisi chrome dan nickel terlebih dahulu harus diketahui untuk mendapatkan komposisi parameter yang tepat.

\section{TEORI}

Berbicara tentang teknologi pengerjaan logam, proses elektroplating dikategorikan sebagai proses pengerjaan akhir (metal finishing). Secara sederhana, elektroplating dapat diartikan sebagai proses pelapisan logam, dengan menggunakan bantuan arus listrik dan senyawa kimia tertentu guna memindahkan partikel logam pelapis ke material yang hendak dilapis. Pelapisan logam dapat berupa lapis seng (zink), galvanis, perak, emas, brass, tembaga, nikel dan krom. Penggunaan lapisan tersebut disesuaikan dengan kebutuhan dan kegunaan masingmasing material. Perbedaan utama dari pelapisan tersebut selain anoda yang digunakan adalah larutan elektrolisisnya. Gambar skema dasar proses elektroplating

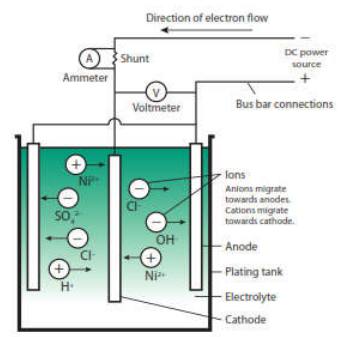

Gambar 1. Skema Dasar Proses Elektroplating

Elektroplating dibuat dengan jalan mengalirkan arus listrik melalui larutan antara logam atau material lain yang konduktif. Dua buah plat logam merupakan anoda dan katoda dihubungkan pada kutub positif dan negatif terminal sumber arus searah (DC). Logam yang terhubung dengan kutub positif disebut anoda dan yang terhubung dengan kutub negatif disebut katoda. Ketika sumber tegangan digunakan pada elektrolit, maka kutub positif mengeluarkan ion bergerak dalam larutan menuju katoda dan disebut sebagai kation. Kutub negatif juga mengeluarkan ion, bergerak menuju anoda dan disebut sebagai anion. Larutannya disebut elektrolit. Hubungan antara voltase dalam elektrolit dan kekuatan arus listrik yang mengalir ditunjukkan oleh hukum Ohm yaitu:

$$
I=\frac{V}{R}
$$

$$
\begin{aligned}
\text { Dimana } & \mathrm{I} \\
& \mathrm{V}=\text { arus listrik (ampere) } \\
& \mathrm{R}=\text { tegangan listrik (volt) } \\
& =\text { Hambatan (ohm) }
\end{aligned}
$$

Arus total yang mengalir melalui sistem menghasilkan perhitungan besar logam yang terlapiskan. Dalam proses lapis listrik (elektroplating) yang lebih penting adalah ketebalan rata-rata, bukan berat total logam yang terendapkan. Ketebalan rata-rata akan tergantung pada berat total logam yang diendapkan dan luas permukaan dimana endapan menyebar. Dalam hal ini satu variabel yang dikenal dengan rapat arus sangat penting untuk diperhatikan. Rapat arus didefinisikan sebagai jumlah arus pada suatu luas permukaan tertentu yang biasa dinyatakan sebagai Ampere $/ \mathrm{m}^{2}$. 
Proses pelapisan nikel merupakan salah satu proses akhir yang banyak diterapkan dalam industri barang-barang logam. Proses lapis listrik yang terjadi merupakan proses pelapisan yang dilakukan dalam media larutan elektrolit dengan bantuan arus listrik searah. Larutan elektrolit nikel yang banyak digunakan dalam dekade sekarang adalah hasil modifikasi watts, yang diumumkan tahun 1916 oleh Prof O.P Watts sendiri, dimana dalam larutan digunakan garam nikel klorida sebagai pelapisan nikel terjadi pembentukan lapisan di atas permukaan katoda/benda kerja dengan mereduksi ion-ion logam pelapis yang menempel pada benda kerja tersebut. Oleh karena itu prosesnya disebut proses pelapisan katodik. Pelapisan menggunakan nikel dapat dilakukan dengan berbagai jenis larutan elektrolit. Lapisan nikel dapat diklasifikasikan menurut jenis larutan elektrolit yang digunakan diantaranya terdapat larutan watt's (watt's bath), larutan sulfat (all sulfate bath), larutan klorida (all choride bath), larutan nikel hitam (black nikel bath), larutan nikel suram (cold bath).

\section{Pengolahan Citra}

Pengolahan citra (image processing) merupakan proses mengolah pixel-pixel di dalam citra digital untuk tujuan tertentu. Pengolahan citra dilakukan karena beberapa alasan yaitu untuk mendapatkan citra asli dari suatu citra yang mengalami penurunan kualitas karena pengaruh derau atau untuk memperoleh citra dengan karakteristik dan cocok secara visual yang dibutuhkan untuk tahap lebih lanjut dalam proses analisis citra. Citra yang diolah ditransformasikan kedalam bentuk representasi numerik untuk pemrosesan secara digital oleh komputer (Mulyanto, 2007).

Pengolahan citra dikelompokkan menjadi dua yaitu memperbaiki citra sesuai dengan kebutuhan dan mengolah informasi yang terdapat di dalam citra. Mengolah informasi dalam citra umumnya untuk mengolah objek citra dengan cara mengekstraksi informasi penting yang ada di dalamnya. Dengan pengolahan citra diharapkan citra yang diproses dapat diambil cirinya (Usman, 2005). Pengolahan citra dilakukan dengan menggunakan operasi tertentu. Salah satu operasi untuk pengolahan citra yaitu perbaikan kualitas citra (image inhancement). Operasi ini bertujuan untuk memperbaiki citra dengan cara memanipulasi parameter-parameter citra.
Operasi ini meliputi perbaikan kontras, Edge inhancement, penajaman (sharpning), pemberian warna semu, dan penapisan derau (Fadlisyah dkk, 2008).

Pengolahan citra merupakan proses pengolahan dan analisis citra yang banyak melibatkan persepsi visual. Proses ini mempunyai ciri data masukan dan informasi keluaran yang berbentuk citra. Istilah pengolahan citra digital secara umum didefinisikan sebagai pemrosesan citra dua dimensi dengan komputer (Basuki dkk, 2005). Pengolahan Citra Digital adalah ilmu yang mempelajari hal-hal yang berkaitan dengan perbaikan kualitas gambar (peningkatan kontras, transformasi warna, restorasi citra), transformasi gambar (rotasi, translasi, skala, tranformasi geometrik), melakukan pemilihan citra ciri (feature images) yang optimal untuk tujuan analisis, melakukan proses penarikan informasi atau deskripsi obyek yang terkandung pada citra, melakukan kompresi atau reduksi data untuk tujuan penyimpanan data, transmisi data, dan waktu proses data. Input dari pengolahan citra adalah citra, sedangkan outputnya adalah citra hasil pengolahan. Pengolahan citra adalah pemrosesan citra dengan maksud untuk mendapatkan kualitas citra yang diinginkan (Munir, 2004). Berikut ini langkah-langkah dalam pengolahan citra antara lain (Nalwan, 1997):

\section{Analisis Citra}

Analisis citra adalah kegiatan menganalisis citra sehingga menghasilkan informasi untuk menetapkan keputusan (biasanya didampingi bidang ilmu kecerdasan buatan / Al yaitu pengenalan pola (pattern recognition) menggunakan jaringan syaraf tiruan, logika fuzzy, dan lain-lain). Gambar berikut menunjukan skema langkah-langkah dalam pengolahan citra secara umum.

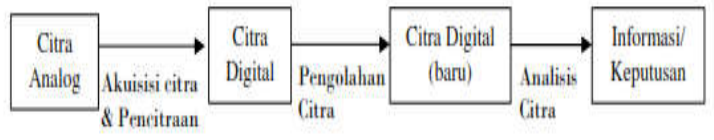

Gambar 2. Image processing steps

\section{Operasi Titik}

Setiap titik pada citra memiliki 2 buah karakteristik, yaitu koordinat yang menunjukkan lokasi dari titik tersebut di dalam citra serta nilai yang menunjukkan tingkat 
keabuan/warna dari titik tersebut. Operasi titik dilakukan dengan memodifikasi nilai skala keabuan dari titik (pixel) yang ditinjau berdasarkan fungsi tertentu, yang disebut sebagai fungsi transformasi skala keabuan (gray scale transformation/GST). Fungsi ini memetakan tingkat keabuan input $(K i)$ ke citra keabuan citra output $(K o)$.

\section{Delphi}

Delphi adalah suatu bahasa pemograman (development language) yang digunakan untk merancang suatu aplikasi program. Delphi termasuk dalam pemrograman bahasa tingkat tinggi (high level language). Maksud dari bahasa tingkat tinggi yaitu perintah-perintah programnya menggunakan bahasa yang mudah dipahami oleh manusia. Bahasa pemrograman Delphi disebut bahasa prosedural artinya mengikuti urutan tertentu. Dalam membuat aplikasi perintah-perintah, Delphi menggunakan lingkungan pemrograman visual. Delphi merupakan generasi penerus dari Turbo Pascal. Pemrograman Delphi dirancang untuk beroperasi dibawah sistem operasi Windows.

\section{Webcam}

WebCam adalah kamera video sederhana berukuran relatif kecil. Sering digunakan untuk konferensi video jarak jauh atau sebagai kamera pemantau. Webcam pada umumnya tidak membutuhkan kaset atau tempat penyimpanan data, data hasil perekaman yang didapat langsung ditransfer ke komputer. Definisi yang lain tentang webcam adalah sebuah periferal berupa kamera sebagai pengambil citra/gambar dan mikropon (optional) sebagai pengambil suara/audio yang dikendalikan oleh sebuah komputer atau oleh jaringan komputer.

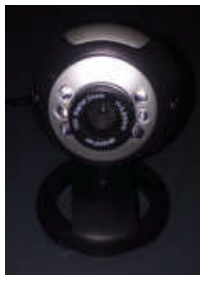

\section{Gambar 3. Webcam}

Gambar yang diambil oleh webcam ditampilkan ke layar monitor,karena dikendalikan oleh komputer maka ada interface atau port yang digunakan untuk menghubungkan webcam dengan komputer atau jaringan. Ada beberapa orang mengartikan WebCam sebagai Web pages dan Camera, karena dengan menggunakan webcam untuk mengambil gambar video secara aktual bisa langsung diupload bila komputer yang mengendalikan terkoneksi internet (Anonymous, 2009).

\section{METODOLOGI}

Penelitian yang dilakukan terdiri dari beberapa tahapan yang membutuhkan referensi, metode yang tepat dan eksperimen, rancangan tersebut dituangkan dalam gambar 4 yaitu:

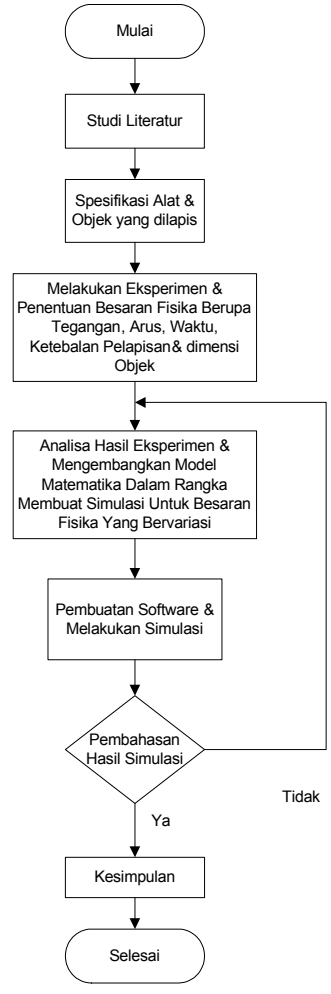

Gambar 4. Diagram alir Rancangan Penelitian

\section{Cara Kerja Sistem}

Pengembangan sistem elektroplating berbasis image processing yang dirancang dalam penelitian ini dapat dilihat pada gambar dibawah ini.

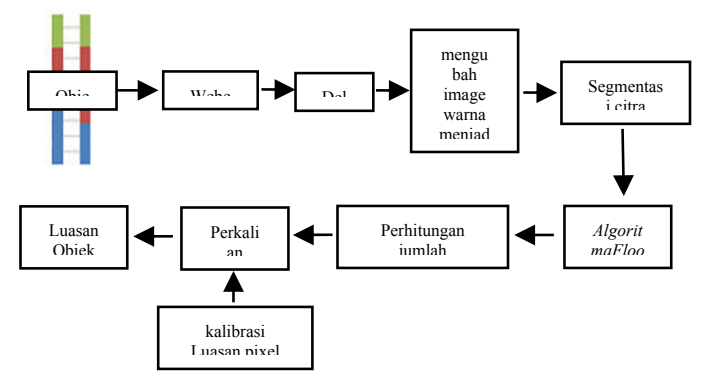

Gambar 5. Diagram Blok Kerja Sistem 
Gambar 5 merupakan diagram blok sistem dengan deskripsi sebagai berikut:

1. Image sensing Webcam atau kamera merupakan sebuat alat optik yang hampir mirip dengan fungsi mata kita. Komponen pada elemen-elemen dasar lensa yaitu: lensa cembung, celah diafragma, dan film. Sebuah periferal berupa kamera sebagai pengambil citra/ gambar dan mikropon (optional) sebagai pengambil suara/ audio yang dikendalikan oleh sebuah komputer atau oleh jaringan komputer.

2. Delphi, sebagai software pengolah data untuk memproses data citra digital.

3. Citra Skala Keabuan (Gray Scale) merupakan citra digital yang hanya memiliki satu nilai kanal pada setiap pikselnya, dengan kata lain nilai bagian red, green dan blue memiliki warna yang sama, yaitu warna dari hitam, keabuan, dan putih. Nilai tersebut digunakan untuk menunjukan tingkat intensitas. Tingkatan keabuan disini merupakan warna abu dengan berbagai tingkatan dari hitam hingga mendekati putih.

4. Segmentasi citra, faktor kunci dalam mengekstraksi ciri adalah kemampuan mendeteksi keberadaan tepi (edge) dari objek di dalam citra. Setelah tepi objek diketahui, langkah selanjutnya dalam analisa citra adalah segmentasi, yaitu mereduksi citra menjadi objek atau region, misalnya memisahkan objek-objek yang berbeda dengan mengekstraksi batasbatas objek (boundary).

5. Metode Floodfill, Metode ini dimulai pada titik $(x, y)$ dan mendefinisikan seluruh pixel pada bidang tersebut dengan warna yang sama. Bila bidang yang akan diisi warna mempunyai beberapa warna, pertama-tama yang dilakukan adalah membuat nilai pixel yang baru, sehingga semua pixel mempunyai warna yang sama pada titik awal warna dituang dinamakan dengan titik bakar.

6. Perhitungan banyaknya piksel dari terhadap image objek yang dibatasi.

7. Kalibrasi luasan dengan membandingkan luas sebenarnya dengan banyak piksel yang sudah terhitung.

\section{HASIL DAN PEMBAHASAN}

Data Percobaan Proses Pelapisan dengan Bright Nickel

Data dibawah ini menampilkan hasil percobaan pelapisan dengan logam bright nickel, dengan waktu pelapisan tetap selama 38 detik, tegangan sebesar 7.5 volt, untuk memperoleh ketebalan sebesar $7.5 \mu \mathrm{m}$, dengan variasi luasan yang berbeda-beda. Hasil percobaan ini ditunjukkan pada tabel 1.

Tabel 1 Data Percobaan Proses Pelapisan dengan Bright Nickel

\begin{tabular}{|c|c|c|c|c|c|}
\hline No & Jenis Part & $\begin{array}{c}\text { Luas } \\
\left(d m^{2}\right)\end{array}$ & $\begin{array}{c}\text { Arus } \\
(\mathrm{A})\end{array}$ & $\begin{array}{c}\text { Kerapatan } \\
\text { Arus } \\
\left(\mathrm{A} / \mathrm{dm}^{2}\right)\end{array}$ & $\begin{array}{c}\text { Ketebalan } \\
(\mu \mathrm{m})\end{array}$ \\
\hline \hline 1 & Part A & 16.32 & 80 & 4.90 & 7.5 \\
\hline 2 & Part B & 20.1 & 105 & 5.37 & 7.5 \\
\hline 3 & Part C & 22.6 & 118 & 5.09 & 7.5 \\
\hline 4 & Part D & 23.04 & 120 & 5.21 & 7.5 \\
\hline
\end{tabular}

Grafik Perbandingan Antara I (Arus) Dengan Ketebalan Tetap

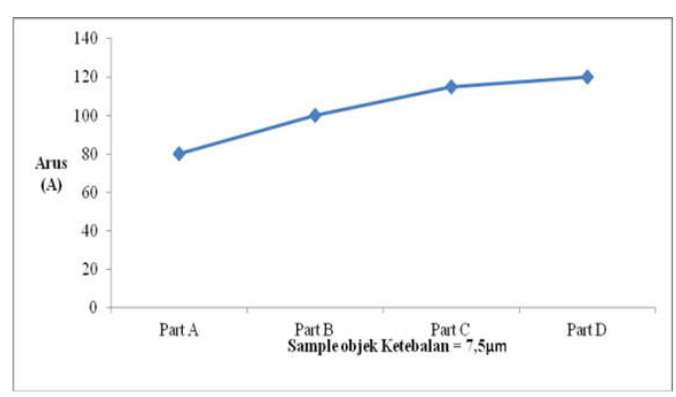

Gambar 6. Grafik Perbandingan Arus Dengan Ketebalan Nickel

Grafik diatas menunjukan bahwa hubungan antara ketebalan dengan arus yang dibutuhkan untuk melakukan pros22555es pelapisan, pada sumbu $X$ menunjukan beberapa sampel part yang memiliki nilai luasan yang berbeda, tetapi target ketebalan lapisan yang ingin dicapai adalah sama yaitu sebesar $\pm 7,5 \mu \mathrm{m}$.

Grafik Perbandingan Antara Kerapatan Arus (J) Dengan Waktu Pelapisan (t) Yang Tetap

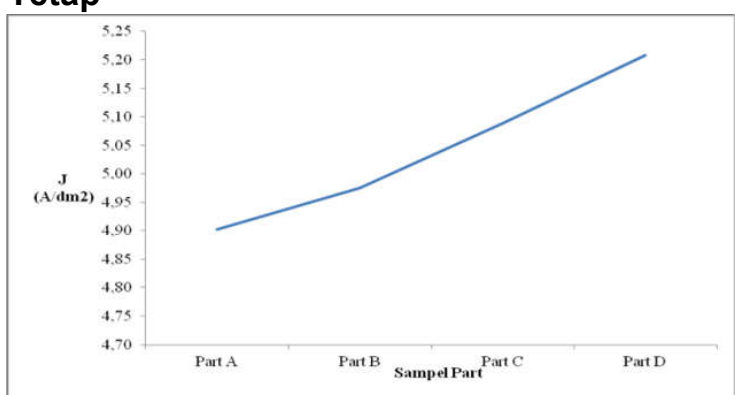

Gambar 7. Grafik Perbandingan Kerapatan Arus Dengan Waktu Nickel

Grafik diatas menunjukan hubungan yang linier antara kerapatan arus dengan waktu pelapisan. Keempat sampel part dilapisi pada waktu yang sama selama 38 detik.

\section{Data Pelapisan Dengan Lapisan Copper}

Data dibawah ini menampilkan hasil percobaan pelapisan dengan logam tembaga 
(copper), dengan waktu pelapisan tetap selama 360 detik, tegangan sebesar 4,37 volt, untuk memperoleh ketebalan rata-rata sebesar $10 \mu \mathrm{m}$, dengan variasi luasan yang berbedabeda. Hasil percobaan ini ditunjukkan pada tabel 2.

Tabel 2 Data Pelapisan Dengan Lapisan Copper

\begin{tabular}{|c|c|c|c|c|c|}
\hline No & Jenis Part & Arus & Luas Area & $\begin{array}{c}\text { Rapat arus } \\
\left(\mathrm{A} / d m^{2}\right)\end{array}$ & Tebal \\
\hline & & & & & $(\mu \mathrm{m})$ \\
\hline 1 & Sampel E & 20 & 3.2 & 6.25 & 9.8 \\
\hline 2 & Sampel F & 40.5 & 6.4 & 6.33 & 10 \\
\hline 3 & Sampel H & 63 & 9.28 & 6.79 & 9.7 \\
\hline 4 & Sampel I & 70 & 10.6 & 6.60 & 10.1 \\
\hline 5 & Sampel J & 85 & 12.8 & 6.64 & 9.8 \\
\hline
\end{tabular}

\section{Grafik Perbandingan Antara I (Arus) Dengan Ketebalan (Thickness)}

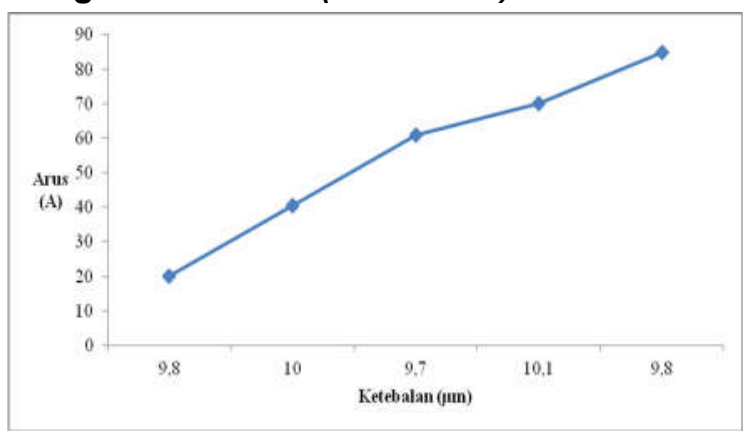

Gambar 8. Grafik Perbandingan Arus Dengan

$$
\text { Ketebalan Copper }
$$

Grafik diatas menunjukan hubungan yang linier antara kerapatan arus dengan ketebalan lapisan. Keempat part sampel dilapisi pada waktu yang sama selama 360 detik dengan target ketebalan rata-rata $10 \mu \mathrm{m}$.

\section{Grafik Perbandingan Antara Kerapatan}

\section{Arus (J) Dengan Waktu Pelapisan (t)}

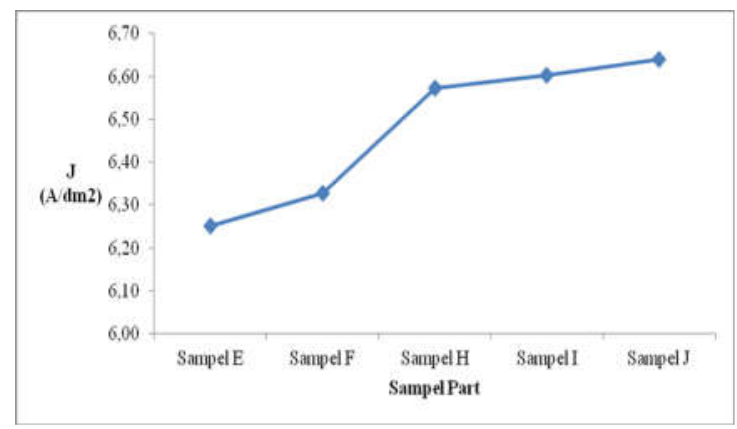

Gambar 9. Grafik Perbandingan Kerapatan Arus Dengan Waktu Copper

Hubungan antara kerapatan arus dengan waktu pelapisan terlihat grafik yang hampir linier, waktu pelapisan yang dibuat tetap selama 360 detik. Kerapatan arus di tentukan oleh luas permukaan sampel yang akan dilapisi.

Penentuan Model Matematika Untuk Besaran Arus Pada lapisan Nickel Dengan Analysis Tool Pack

Tabel hasil percobaan pelapisan dengan nickel menunjukan hubungan antara luas permukaan objek yang akan dilapisi terhadap arus yang dibutuhkan untuk proses pelapisan. Hal itu pun akan mempengaruhi harga dari kerapatan arus. Untuk mengetahui hubungan antara luas permukaan dengan rapat arus selain dengan menggunakan hasil percobaan, penelitian ini mengambil referensi dari buku tentang pelapisan nikel dengan diperoleh data sebagai berikut:

Tabel 3 Referensi Nilai Ketebalan Lapisan

\section{Nikel Terhadap Kerapatan Arus}

\begin{tabular}{|l|l|l|l|l|l|l|l|l|}
\hline \multicolumn{7}{|c|}{ Time in minutes to deposit the indicated average thickness of } \\
nickel at various current densities. \\
\hline $\begin{array}{l}\text { Current } \\
\text { Density } \\
(\mathrm{A} \mathrm{dm}-2)\end{array}$ & $5 \mu \mathrm{m}$ & $10 \mu \mathrm{m}$ & $15 \mu \mathrm{m}$ & $20 \mu \mathrm{m}$ & $25 \mu \mathrm{m}$ & $30 \mu \mathrm{m}$ & $40 \mu \mathrm{m}$ & $50 \mu \mathrm{m}$ \\
\hline 1 & 26 & 51 & 77 & 100 & 128 & 154 & 200 & 255 \\
\hline 1.5 & 17 & 34 & 51 & 68 & 85 & 102 & 140 & 170 \\
\hline 2 & 13 & 26 & 39 & 51 & 65 & 78 & 100 & 130 \\
\hline 2.5 & 11 & 22 & 32 & 42 & 53 & 64 & 84 & 105 \\
\hline 3 & 8.5 & 17 & 26 & 34 & 43 & 52 & 68 & 85 \\
\hline 4 & 6.5 & 13 & 20 & 26 & 33 & 40 & 51 & 65 \\
\hline 5 & 5 & 10 & 15 & 20 & 25 & 30 & 41 & 50 \\
\hline 6 & 4.5 & 8.5 & 13 & 17 & 22 & 26 & 34 & 43 \\
\hline
\end{tabular}

Untuk menentukan hubungan antara nilai arus dengan parameter luasan dibutuhkan penyelesaian dengan model matematika yang hasilnya akan dimasukan pada program simulasi berbasis Delphi. Penentuan rumus atau model matematika untuk mencari arus dengan parameter luasan, tegangan, waktu pelapisan \& ketebalan yang akan dicapai berdasarkan data hasil percobaan dan tabel referensi diatas dengan menggunakan program analysis toolpack. dengan hasil sebagai berikut :

$Y=5,1354 X+1,7978$

Dimana :

$$
\begin{aligned}
& \mathrm{Y}=\text { Arus Listrik (Ampere) } \\
& \mathrm{X}=\text { Luas Permukaan Objek }
\end{aligned}
$$

Dari Model diatas nantinya akan dimasukan kedalam program simulasi sebagai rumus untuk mencari harga arus yang dicari. 


\section{Penentuan Model Matematika Untuk Besaran Arus Pada lapisan Copper Dengan Analysis Tool Pack}

Untuk mendapatkan model matematika dalam mencari harga arus pada proses pelapisan dengan logam copper, maka dilakukan pendekatan dengan metode regresi linier dengan menggunakan analysis tool pack sehingga diperoleh perhitungan sebagai berikut :

$\mathrm{Y}=14.63 \mathrm{x}+3.521$

Dimana :

$$
\begin{aligned}
& Y=\text { Arus Listrik (Ampere) } \\
& X=\text { Luas Permukaan Objek }
\end{aligned}
$$

Hasil pemodelan diatas nantinya akan dimasukan kedalam program simulasi sebagai rumus untuk mencari harga arus yang dicari. Masing-masing nilai intersept dan koefisien pada model matematika diatas mempunyai perkiraan standar kesalahan.

\section{Perhitungan Luasan Objek}

Proses perhitungan objek benda dilakukan dengan melakukan perhitungan terhadap jumlah piksel yang dihitung pada tepi objek permukaan. Untuk mendapatkan luasan yang tepat harus dilakukan kalibrasi piksel sehingga didapatkan nilai piksel dalam satuan $d m^{2}$.

Nilai Piksel $=\frac{\text { Luas Objek sebanarnya }}{\text { Banyaknya Piksel }}$

Jarak pengambilan gambar objek ditetapkan pada jarak $25 \mathrm{~cm}$. Untuk menentukan kalibrasi piksel, mengambil sebuah sampel benda dengan luas $0,88 \mathrm{dm}^{2}$ pada jarak $25 \mathrm{~cm}$, didapatkan total piksel 50373, sedangkan objek yang dimaksud adalah daerah yang dibatasi tepi, dan memiliki jumlah piksel sebanyak 40986, Sehingga didapatkan hasil kalibrasi dengan luas per piksel dengan perhitungan sebagai berikut:

Nilai Piksel $=\frac{0,88 \mathrm{dm}^{2}}{40986}=0,002147 \mathrm{dm}^{2} /$ piksel

\section{Data Hasil Simulasi dengan Lapisan Nikel}

Simulasi dilakukan dengan memasukan nilai luasan yang berbeda sehingga didapatkan hasil sebagai berikut. Berdasarkan beberapa sampel luasan didapat hubungan antara luas dengan arus listrik yang dibutuhkan untuk proses pelapisan yaitu nilai tegangan, ketebalan, dan waktu dibuat konstan.

Tabel 4 Data Simulasi Proses Elektroplating Dengan Lapisan Nikel

\begin{tabular}{|c|c|c|c|c|c|c|c|}
\hline No & Jenis Part & $\begin{array}{c}\text { Luas } \\
\left(\mathrm{dm}^{2}\right)\end{array}$ & $\begin{array}{c}\text { Waktu } \\
(\mathrm{detik})\end{array}$ & $\begin{array}{c}\text { Tegangan } \\
(\mathrm{V})\end{array}$ & $\begin{array}{c}\text { Arus } \\
(\mathrm{A})\end{array}$ & $\begin{array}{c}\text { Rapat Arus } \\
\left(\mathrm{A} / \mathrm{dm}^{2}\right)\end{array}$ & $\begin{array}{c}\text { Ketebalan } \\
(\mu \mathrm{m})\end{array}$ \\
\hline \hline 1 & Simulasi 1 & 3 & 39 & 7.5 & 17.2 & 5.73 & 7.5 \\
\hline 2 & Simulasi 2 & 6 & 39 & 7.5 & 32.61 & 5.44 & 7.5 \\
\hline 3 & Simulasi 3 & 4.5 & 39 & 7.5 & 24.91 & 5.53 & 7.5 \\
\hline 4 & Simulasi 4 & 6.5 & 39 & 7.5 & 35.18 & 5.41 & 7.5 \\
\hline 5 & Simulasi 5 & 7 & 39 & 7.5 & 37.75 & 5.39 & 7.5 \\
\hline 6 & Simulasi 6 & 9 & 39 & 7.5 & 48.02 & 5.34 & 7.5 \\
\hline 7 & Simulasi 7 & 12 & 39 & 7.5 & 63.42 & 5.29 & 7.5 \\
\hline 8 & Simulasi 8 & 15 & 39 & 7.5 & 78.83 & 5.26 & 7.5 \\
\hline 9 & Simulasi 9 & 18 & 39 & 7.5 & 94.23 & 5.24 & 7.5 \\
\hline 10 & Simulasi 10 & 22 & 39 & 7.5 & 114.78 & 5.22 & 7.5 \\
\hline
\end{tabular}

Data Hasil Simulasi dengan Lapisan Copper

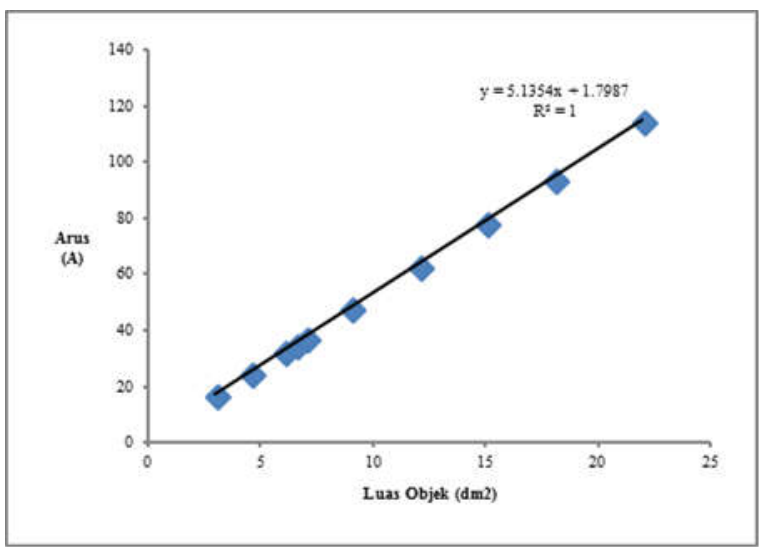

Gambar 10. Grafik Simulasi Hubungan Arus dengan Luas Objek pada Pelapisan Nikel

Simulasi kedua mempunyai prosedur yang sama yaitu dengan memasukan nilai luasan yang berbeda sehingga didapatkan hasil sebagai berikut.

Tabel 5 Data Hasil Simulasi Proses Elektroplating dengan Lapisan Copper

\begin{tabular}{|c|c|c|c|c|c|c|c|}
\hline No & Jenis Part & $\begin{array}{c}\text { Luas } \\
\left(d m^{2}\right)\end{array}$ & $\begin{array}{c}\text { Arus } \\
(\mathrm{A})\end{array}$ & $\begin{array}{c}\text { Tegangan } \\
(\mathrm{V})\end{array}$ & $\begin{array}{c}\text { Waktu } \\
(\mathrm{detik})\end{array}$ & $\begin{array}{c}\text { Rapat arus } \\
\left(\mathrm{A} / \mathrm{dm}^{2}\right)\end{array}$ & $\begin{array}{c}\text { Tebal } \\
(\mu \mathrm{m})\end{array}$ \\
\hline \hline 1 & Sampel E & 2 & 11.35 & 4.36 & 360 & 5.68 & 10 \\
\hline 2 & Sampel F & 6 & 38.58 & 4.38 & 360 & 6.43 & 10 \\
\hline 3 & Sampel H & 8 & 52.2 & 4.38 & 360 & 6.52 & 10 \\
\hline 4 & Sampel I & 9,5 & 62.41 & 4.36 & 360 & 6.56 & 10 \\
\hline 5 & Sampel J & 11 & 72.62 & 4.36 & 360 & 6.60 & 10 \\
\hline
\end{tabular}

Terlihat perbandingan yang linier antara luas permukaan objek yang dilapisi terhadap arus yang mengalir. Hal ini dapat dilihat dari grafik dibawah ini. 


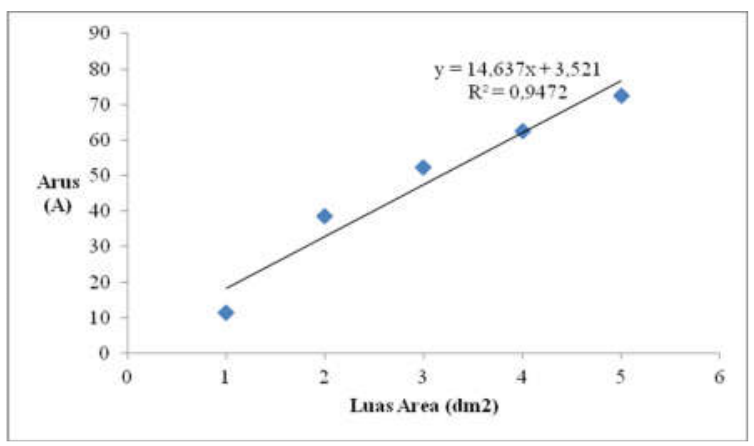

Gambar 11. Grafik Simulasi Hubungan Arus dengan

$$
\text { Luas Objek pada Pelapisan Copper }
$$

\section{KESIMPULAN}

Berdasarkan hasil dari penelitian dan simulasi yang dilakukan, terdapat beberapa kesimpulan diantaranya sebagai berikut:

1. Perubahan arus dan kerapatan arus terhadap luas permukaan yang dilapisi dengan nickel memiliki karakteristik hubungan yang linier dengan beberapa parameter seperti waktu pelapisan konstan selama 39 detik dan tegangan sebesar 7,5 volt.

2. Perubahan arus dan kerapatan arus terhadap luas permukaan yang dilapisi dengan copper memiliki karakteristik hubungan yang linier dengan beberapa parameter seperti waktu pelapisan konstan selama 360 detik dan tegangan sebesar 4,36 volt.

3. Program simulasi berbasis Delphi, dimana perhitungan proses elektroplating dengan bahan pelapis nickel dan copper hanya merubah satu variabel saja berupa arus dimana input yang mempengaruhi arusnya yaitu luas permukaan objek, dengan hasil yang didapatkan mendekati data hasil percobaan.

\section{UCAPAN TERIMAKASIH}

Ucapan terima kasih saya haturkan kepada Prof.Dr.Masbah yang telah banyak membimbing, tidak lupa juga semua rekanrekan ISTN yang telah banyak membantu penelitian ini.

\section{DAFTAR PUSTAKA}

1. Nickel Institute. 2014. Nickel Plating Hand book. Brussel : Nickel Institute

2. Azhar Ahmad, Muhammad. 2011. Analisa
Pengaruh
Besar
Tegangan
Listrik
Terhadap Ketebalan Pelapisan Chrom

\section{pada Pelat Baja dengan Proses Elektroplating, UNHAS}

3. This experiment is based on Experiment 21 in Advanced Chemistry with Vernier, Vernier Software and Technology, Beaverton. OR, 2015.

4.Science Company, "Patina Formulas for Brass, Bronze, and Copper," last accessed 2016 :

5.Chappell, William, Electroplating Copper Process Specipication, Purdue University. 2007

6. R. Gonzalez and R. Woods. Digital Image Processing, Prentice Hall, 2008.

7. Nick Efford, Digital Image Processing, a practical introduction using Java, Addison Wesley, USA, 2000.

8. Ayu Ida SA, Optimasi Waktu dan Jarak Elektrode Terhadap Ketebalan Dan Kekerasan Lapisan Krom Pada Stoneware Dan Earthware, Universitas Mataram, 2007 